\title{
IMPLEMENTASI E-GOVERNMENT PADA SITUS WEB PEMERINTAH MENUJU TATA KELOLA PEMERINTAHAN BERBASIS OPEN GOVERNMENT DI PROVINSI JAMBI
}

\author{
IMPLEMENTATION OF E-GOVERNMENT ON GOVERNMENT WEBSITE TOWARDS \\ GOVERNMENT GOVERNANCE BASED ON OPEN GOVERNMENT IN JAMBI PROVINCE
}

\author{
Cholillah Suci Pratiwi \\ Fakultas IImu Sosial dan IImu Politik Universitas Jambi \\ Jl. Jambi Muaro Bulian Km 15 Mandalo Darat Jambi \\ email: cholilahsucipratiwi@yahoo.com
}

\begin{abstract}
This study aims to determine how long Jambi Province government implements e-government in its government by utilizing technology. This research uses descriptive qualitative method by observing all official sites of the Local Government in Jambi Province to obtain primary data. At present, government agencies in Jambi Province have taken the initiative to develop public services through communication and information networks in the form of websites. However, the implementation of the majority of provincial regional government websites, Jambi District /City is still at the first level (preparation) and only a small percentage has reached level two (maturation), while level three (stabilization) and four (utilization) have not been achieved. That is, the implementation of egovernment in Jambi Province is only at an early stage, so that many government institutions claiming that they have applied e-government are only at the stage of web presence. The main challenge lies in the ability and readiness of management and actors and not e-government support technologies. If this is not addressed, it can result in the emergence of a digital divide. Furthermore, transparency of policies and the implementation of regional autonomy will be increasingly difficult to manage and will close the path towards perfect democratization. So to improve the management of e-government the Jambi Provincial government must improve human resources, change the culture or work culture that can affect the government's performance in e-government development. The essence of the purpose of implementing e-government is that the government can implement a practice called good governance in the form of a social contract that demands democratization of the administration of government. If the Jambi Provincial government is committed to doing this seriously, it will support the optimization of e-government as a form of achieving open government in Jambi Province.
\end{abstract}

Keywords: Implementation, E-government, Open Government.

Abstrak
Penelitian ini bertujuan untuk mengetahui sejauh mana pemerintah Provinsi Jambi melaksanakan e-
government dalam pemerintahannya dengan memanfaatkan teknologi. Penelitian ini menggunakan
metode kualitatif deskriptif dengan melakukan observasi pada seluruh situs/website resmi Pemerintah
Daerah di Provinsi Jambi untuk mendapatkan data-data yang bersifat primer. Saat ini instansi
pemerintah di Provinsi Jambi sudah berinisiatif mengembangkan pelayanan publik melalui jaringan
komunikasi dan informasi dalam bentuk situs web. Namun, implementasi mayoritas situs web
pemerintah daerah Provinsi, Kabupaten/Kota Jambi masih berada pada tingkat pertama (persiapan)
dan hanya sebagian kecil yang telah mencapai tingkat dua (pematangan), sedangkan tingkat tiga
(pemantapan) dan empat (pemanfaatan) belum tercapai. Artinya, implementasi e-government di
Provinsi Jambi baru pada tahap awal, sehingga banyak lembaga pemerintah yang menyatakan dirinya
sudah mengaplikasikan e-government, ternyata baru pada tahap web presence. Tantangan utama
terletak pada kemampuan dan kesiapan manajemen serta para pelaku dan bukannya teknologi
pendukung e-government. Apabila hal tersebut tidak diatasi maka dapat mengakibatkan timbulnya
digital divide. Lebih jauh lagi transparansi kebijakan dan pelaksanaan otonomi daerah akan semakin
sulit dikelola dan akan menutup jalan ke arah demokratisasi yang sempurna. Maka untuk
meningkatkan pengelolaan e-government pemerintah Provinsi Jambi harus meningkatkan sumber
daya manusia, merubah kultur atau budaya kerja yang dapat mempengaruhi kinerja pemerintah
dalam pengembangan e-government. Hakekat tujuan diterapkannya e-goverment adalah agar
pemerintah dapat menerapkan suatu praktik yang disebut sebagai good governance berupa suatu
kontrak sosial yang menuntut demokratisasi terhadap pelaksanaan administrasi pemerintahan. Jika

109 | Khazanah IntelektualVolume 2 Nomor 1 Tahun 2018 
pemerintah Provinsi Jambi berkomitmen melakukan hal ini secara serius, maka akan menunjang optimalisasi e-government sebagai bentuk tercapainya open government di Provinsi Jambi.

Kata kunci : Impelementasi, E-government, Open Government

\section{PENDAHULUAN}

Perkembangan teknologi informasi dan komunikasi yang tidak dapat cegah, keadaan seperti ini menuntut warga negara untuk terus bergerak dinamis dalam menghadapi setiap tantangan teknologi informasi dan komunikasi yang semakin canggih, hingga pada akhirnya perkembangan teknologi dan Informasi mempengaruhi perubahan segala aspek kehidupan bernegara baik di bidang ekonomi, sosial, pendidikan, pertahanan dan keamanan, politik, dan pemerintahan. Dalam mengatasi hal tersebut maka pemerintah memberlakukan Intruksi Presiden Republik Indonesia Nomor 3 Tahun 2003 Tentang Kebijakan dan Strategi Nasional Pengembangan E-government dalam pemanfaatan teknologi informasi dan komunikasi yang bertujuan untuk meningkatkan efisiensi, efektifitas, transparansi dan akuntabilitas penyelenggaraan pemerintahan.

\section{Pemanfaatan perkembangan}

teknologi informasi dan komunikasi yang dimaksud yaitu melalui pengelolaan egovernment sebagai media dalam memecahkan masalah yang semula bersifat konsevatif menjadi lebih inovatif.(Anggono, 2013) Fungsi e-government semakin kuat dengan adanya keterbukaan informasi publik sebagai tujuan utama open government Indonesia. Sejauh ini telah terdapat beragam aplikasi ataupun web portal dan website pemerintah lainnya, tujuannya adalah untuk menunjang transparansi dan akuntabilitas serta mempermudah masyarakat memperoleh informasi yang dibutuhkan, layanan publik yang efisien dan efektif, bahkan masyarakat dapat melakukan pengawasan terhadap kinerja lembaga pemerintahan maupun pelayanan publik dalam portal satu layanan. (Djumadal, 2013) Bahkan masyarakat dapat memberikan masukan, pengaduan melalui aplikasi ataupun web yang disediakan oleh pemerintah.

Selain itu, dalam penelitian Sosiawan (2014) dijelaskan bahwa inovasi baru lainnya ialah portal satu pemerintah yang menyediakan beragam informasi terkait instansi pemerintah, dimana mencakup program kerja, anggaran dan lainnya terdapat dalam situs web resmi pemerintah baik pusat dan daerah yang dapat diakses dengan mudah oleh masyarakat. Sehingga, e-government menjadi jembatan yang dapat meningkatkan peran masyarakat sebagai warga negara yaitu dengan cara berpartisipasi dalam pembangunan, pengawasan dan bisa berkolaborasi memberikan inovasi bersama demi terciptanya pemerintahan yang baik untuk kesejahteraan masyarakat. Dengan terlaksananya e-government maka terdapat 3 komponen yang terpenuhi dalam konsep open government yaitu, pertama, 
terciptanya akuntabilitas dengan memberikan informasi publik yang dapat dengan mudah diakses oleh masyarakat. Kedua, terciptanya transparansi, sehingga membangkitkan kembali kepercayaan publik terhadap kinerja pemerintah. Ketiga yaitu terciptanya partisipasi publik melalui peran aktif masyarakat dalam pengawasan dan pembangunan. Senada dengan hal ini Maria, Eka Afrina dkk (2015) menyatakan bahwa dengan adanya keterlibatan publik, maka publik dapat mempengaruhi cara kerja pemerintah mereka dengan terlibat dalam proses kebijakan pemerintah dan program pemberian layanan. Pengelolaan egovernment di Provinsi Jambi dapat diketahui berdasarkan grafik berikut:

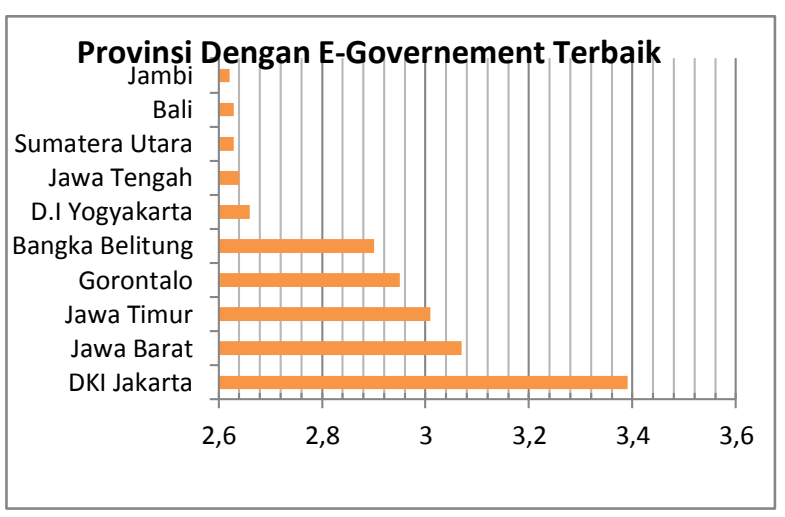

(Sumber : Databoks, Katadata Indonesia 2016)

Berdasarkan grafik diatas, Provinsi Jambi menempatkan posisi paling rendah dibandingkan Provinsi lainnya. hal ini menandakan bahwa pengelolaan $e$ government di Provinsi Jambi belum terlaksana dengan baik. Manfaat website resmi pemerintah Provinsi Jambi juga belum memberikan angka yang signifikan terhadap kepuasan masyarakat dalam memperoleh informasi yang dibutuhkan, sehingga dapat disimpulkan bahwa partisipasi masyarakat belum terlaksana, berbanding terbalik dengan tujuan konsep open government yang tengah digencarkan oleh pemerintah pusat hingga sekarang nyatanya proses pelayanan publik di Provinsi Jambi belum berjalan dengan baik.

Perlu disadari bahwa e-governement memegang peran penting dalam terlaksananya open government dalam menciptakan pemerintahan efektif, efisien dan produktif sebagai indikator keberhasilan reformasi birokrasi yang berbasis open government. (Indrajit, 2014: 21) Ketika dibandingkan dengan Kabupaten dan Kota, penggunaan e-government sudah lebih efektif dan akif dibandingkan dengan website Provinsi Jambi sendiri. Namun, ketersediaan akses tersebut bila dibenturkan dengan karakteristik pemakai (user) atau irregular user internet maka akan terjadi bias. Pada sisi irregular user untuk bisa mengakses informasi dari web sites memerlukan keaktifan, motif pendorong serta kebutuhan akan informasi. Oleh karena itu muncul pertanyaan apakah banyak masyarakat yang benar-benar memanfaatkan dan menggunakan situs web sites internet pemda tersebut untuk mencari dan memperoleh informasi yang dibutuhkan? Pertanyaan lain yang muncul adalah apakah terjadi keseimbangan antara penyampaian informasi dari pihak pemda selaku komunikator dan kontributor informasi dalam website dengan kemampuan, skill, kebutuhan dan tingkat 
eksposure masyarakat untuk mengakses internet secara pribadi ataupun melalui jasa warnet? Pertanyaan lain dari segi teknis apakah strategi design websites tersebut menarik dalam penampilannya serta mampu diakses secara cepat? Hal ini juga menjadi permasalahan tersendiri karena websites yang tidak kreatif dan sulit untuk diakses akan membuat user malas membukanya. Pada sisi lain mengingat kebijakan, peluang implementasi serta hambatan yang ada memunculkan beberapa pertanyaan tentang sampai sejauh mana penerapan atau implementasi e-government yang dilakukan, bagaimana ketersediaan informasi dalam setiap situs web, bagaimana aksesbilitasnya, serta bagaimana strategi pengembangannya. Berangkat dari beberapa pertanyaan tersebut di atas maka tulisan ini mencoba untuk menelaah secara kritis tentang evaluasi implementasi egovernment dalam mendukung terlaksananya tata kelola pemerintahan yang berbasis open government di Provinsi Jambi yang telah dilakukan selama ini.

\section{E-GOVERNMENT}

Pada pelaksanaan e-government, informasi, komunikasi, dan transaksi antara masyarakat dan pemerintah dilakukan via internet. Sehingga ada beberapa manfaat yang dihasilkan seperti misalnya, komunikasi dalam sistem administrasi berlangsung dalam hitungan jam, bukan hari atau minggu. Artinya, pelayanan pemerintah pada masyarakat menjadi sangat cepat, service dan informasi dapat disediakan 24 jam sehari, tujuh hari dalam seminggu. Informasi dapat dicari dari kantor, rumah, bahkan mobile dimanapun tanpa harus secara fisik datang ke kantor pemerintahan atau tempat-tempat pelayanan umum. Akselerasi kecepatan pelayanan berarti juga merupakan penghematan dalam waktu, energi maupun sumber daya. Selain manfaat tersebut, akses informasi ke pemerintah menjadi terbuka sangat sangat lebar sehingga tidak ada lagi istilah 'warga kelas satu' dan 'warga kelas dua' di hadapan pemerintah. Baik pemerintah dan masyarakat dari semua golongan saling terbuka dalam interkasi dan komunikasinya yang mengarah pada keterbukaan (Andrianto, 2015).

Terciptanya keterbukaan (transparansi) diharapkan akan terjadi proses demokratisasi dan trans-paransi politik serta administrasi. (Hutter, 2016: 8) Dengan demikian cara ini akan mampu meminimalisir penyelewengan kebijakan pemerintah, karena transparansi kebijakan dan pelaksanaan otonomi daerah akan makin mudah dikelola dan diawasi.

Manfaat lainnya, pada konteks agenda pembangunan nasional, penerapan e-government dapat membuka peluang bagi pemerintah untuk melakukan re-inventing untuk dapat menjadi lembaga sosial yang lebih dekat (up close) dengan masyarakat, membangun aliansi dan partnership yang lebih erat dengan beberapa komunitas dalam masyarakat yang memiliki kepentingan, praktek, dan keahlian yang berbeda-beda. Model e-government yang 
diterapkan di negara-negara luar adalah menggunakan model empat tahapan perkembangan yang meliputi: (Dwiyanto, 2017)

a) Fase pertama, berupa penampilan website (web presence) yang berisi informasi dasar yang dibutuhkan masyarakat.

b) Fase kedua, fase interaksi yaitu isis informasi yang ditampilkan lebih bervariasi, seperti fasilitas download dan komunikasi e-mail dalam website pemerintah.

c) Fase ketiga, tahap transaksi berupa penerapan aplikasi/formulir untuk secara online mulai diterapkan.

d) Fase Keempat, fase transformasi berupa pelayanan yang terintegrasi, tidak hanya menghubungkan pemerintah dengan masyarakat tetapi juga dengan organisasi lain yang terkait (pemerintah ke antar pemerintah, sektor nonpemerintah, serta sektor swasta).

\section{APLIKASI E-GOVERNMENT}

Wujud nyata dari aplikasi egovernment yang telah umum dilaksanakan dan diatur pelaksanaannya adalah pembuatan situs web pemerintah daerah. Situs web pemerintah daerah merupakan salah satu strategi didalam melaksanakan pengembangan e-government secara sistematik melalui tahapan yang realistik dan terukur.(Junaidi, 2015: 16) Situs web pemerintah daerah merupakan tingkat pertama dalam pengembangan e- government di Indonesia yang memiliki sasaran agar masyarakat Indonesia dapat dengan mudah memperoleh akses kepada informasi dan layanan pemerintah daerah, serta ikut berpartisipasi di dalam pengembangan demokrasi di Indonesia dengan menggunakan media internet. (Buku panduan Kominfo, 2002)

Dari aplikasi tersebut dapat diketahui bahwa pengembangan e-government di Indonesia dilaksanakan melalui 4 (empat) tingkatan, yaitu:

a) Tingkat 1 merupakan tingkat Persiapan berupa pembuatan situs web sebagai media informasi dan komunikasi pada setiap lembaga serta sosialisasi situs web untuk internal dan publik.

b) Tingkat 2 merupakan tingkat Pematangan yang berupa Pembuatan situs web informasi publik yang bersifat interaktif dan Pembuatan antar muka keterhubungan dengan lembaga lain.

c) Tingkat 3, tingkat Pemantapan yang berisi Pembuatan situs web yang bersifat transaksi pelayanan publik dan Pembuatan interoperabilitas aplikasi dan data dengan lembaga lain.

d) Tingkat 4 adalah tingkat Pemanfaatan yang berisi Pembuatan aplikasi untuk pelayanan yang bersifat Government to Government (G2G), Government to Business (G2B), Government to Consumers (G2C). Pada situs web pemerintah 
daerah ada sejumlah kriteria yang ditetapkan oleh Kementrian Komunikasi dan Informasi Republik Indonesia (Kominfo) dalam buku panduan penyelenggaran situs web pemerintah daerah. Kriteria yang diberikan merupakan gambaran ciriciri kunci bentuk dasar situs web pemerintah daerah yang terdiri dari:

1. Fungsi, aksesbilitas, kegunaan; Isi informasi situs web pemerintah daerah berorientasi pada keperluan masyarakat, yaitu menyediakan informasi dan pelayanan yang diinginkan oleh masyarakat. Pada kriteria ini ditekankan adanya anti diskriminasi bagi pengguna, artinya situs web pemerintah daerah dapat dibuka tanpa membedakan fasilitas dan kemampuan komputer yang dimiliki oleh pengguna. Disain situs web pemerintah daerah adalah profesional, menarik, dan berguna. Berita atau artikel yang ditujukan kepada masyarakat sebaiknya disajikan secara jelas, dan mudah dimengerti.

2. Bekerjasama; Situs web pemerintah daerah harus saling bekerjasama untuk menyatukan visi dan misi pemerintah. Semua dokumen pemerintah yang penting harus memiliki URL (Uniform Resource Locator) yang tetap, sehingga mesin pencari (search engine) dapat menghubungkan kepada informasi yang diinginkan secara langsung.
3. Isi yang Efektif; Masyarakat pengguna harus mengetahui bahwa informasi tertentu akan tersedia pada situssitus pemerintah daerah manapun. Pengguna memiliki hak untuk mengharapkan isi dari suatu situs web pemerintah daerah adalah data terbaru dan tepat, serta mengharapkan berita dan materi baru selalu diketengahkan.

4. Komunikasi Dua Arah; komunikasi yang disediakan pada situs web pemda dalam bentuk dua arah (interaktif). Situs web pemerintah daerah harus memberikan kesempatan pengguna untuk menghubungi pihak-pihak berwenang, menjelaskan pandangan mereka, atau membuat daftar pertanyaan mereka sendiri.

5. Evaluasi Kesuksesan: Situs-situs web pemerintah da erah harus memiliki sistem untuk mengevaluasi kesuksesan, dan menentukan apakah situs webnya memenuhi kebutuhan penggunanya. Artinya Situs-situs web pemerintah daerah harus mengumpulkan, minimal, statistik angka pengguna, pengunjung, jumlah halaman, permintaan yang sukses dan tidak sukses, halaman yang sering dikunjungi dan jarang dikunjung, halaman rujukan utama. Informasi tambahan mengenai siapa yang menggunakan situs ini, tingkat transfer data. Evaluasi empat bulanan sangatlah direkomendasikan. 
6. Kemudahan Menemukan Situs ; pihak pemda harus mempromosikan situs webnya dan mendaftarkannya ke mesin pencari. Masyarakat pengguna mungkin tidak bisa menemukan suatu situs web pemerintah daerah kecuali pengelola mempromosikannya dan memastikan bahwa mesin pencari mendaftarkannya. Serta mensosialisaikannya melalui pemberitahuan lewat pers, Hubungan Masyarakat dan brosur.

7. Pelayanan yang diatur dengan baik ; Pihak pemda harus menggunakan sumber yang terpercaya; strategi yang jelas, tujuan, dan target pengguna; serta strategi pengembangan masa depan, termasuk langkah menuju pusat data yang dinamis dari media digital lainnya.

\section{OPEN GOVERNMENT}

Open Government menurut Global Integrity dalam Maria, Eka Afrina dkk (2015: 14) mencakup tiga hal yakni transparansi informasi, keterlibatan publik dan akuntabilitas. Ahmad Djunaedi menyatakan hasil yang diharapkan dari open government berupa pengurangan angka korupsi, peningkatan transparansi, peningkatan kenyamanan, pertambahan pendapatan dan atau pengurangan biaya. Open government dijalankan dengan pemanfaatan inovasi dan teknologi informasi dan komunikasi egovernment.

Prinsip open government dapat dikategorikan sebagai berikut: (Gulati, 2015)
1. Transparansi, dapat diukur menjadi beberapa indikator, yaitu adanya sistem keterbukaan dan standarisasi yang jelas dan mudah dipahami dari semua proses-proses penyelenggaraan pemerintahan. Kedua, adanya mekanisme yang memfasilitasi pertanyaan-pertanyaan publik tentang proses-proses dalam penyelenggaraan pemerintahan. Ketiga, adanya mekanisme pelaporan maupun penyebaran informasi penyimpangan tindakan aparat publik didalam kegiatan penyelenggaraan pemerintahan.

2. Akuntabilitas, dalam penyelenggaraan pemerintahan dituntut disemua tahap mualai dari penyususnan program kegiatan, pembiayaan, pelaksanaan, evaluasinya, maupun hasil dan dampaknya. Untuk mengukur pelaksanaan penyelenggaraan pemerintahan yang kemudian dipublikasikan. Ketika ada pelanggaran, harus ada mekanisme pelaporan dan tindak lanjut terhadap pelanggaran yang terjadi.

3. Partisipasi Publik, masyarakat ikut aktif berperan dalam pemerintahan dan pembangunan. Melalui beberapa cara diantaranya: Pertama, masyarakat terlibat dalam pengawasan, evaluasi anti korpsi dalam siklus kebijakan. Kedua, masyarakat terlibat dalam good governance implementasi kebijakan 
publik (kesehatan, pendidikan, Penelitian ini menggunakan metode administrasi publik, termasuk analisis isi (content analiys) yang pelaporan dan mekanisme merupakan analisis ilmiah tentang isi pesan feedback). Ketiga, saluran umpan komunikasi yang mencakup: (1) klasifikasi balik untuk menutup celah dan tanda, (2) menggunakan kriteria sebagai mengatasi kesalahan pengelolaan. dasar klasifikasi, (3) menggunakan teknik Keempat, lobbying rutin sebagai analisis tertentu sebagai pembuat prediksi. kesempatan untuk memberikan masukan terhadap pengambilan kebijakan. (Moleong, 2005: 44) Kemudian, penelitian ini menggunakan unit-unit analisis dan kategorisasi sebagai berikut:

\section{METODE PENELITIAN}

Tabel 1. Unit Analisis dan Kategorisasi

\begin{tabular}{|c|c|c|}
\hline NO & UNIT ANALISIS & KATEGORISASI \\
\hline \multirow{5}{*}{1} & \multirow{5}{*}{$\begin{array}{l}\text { Informasi menu utama } \\
\text { dalam websites }\end{array}$} & $\begin{array}{l}\text { 1. Potensi daerah, Komoditas utama dan kualitas } \\
\text { SDM }\end{array}$ \\
\hline & & 2. Potensi daerah dan Komoditas utama \\
\hline & & 3. Potensi daerah dan Kualitas SDM \\
\hline & & 4. Komoditas utama dan Kualitas SDM \\
\hline & & 5. bukan salah satu dari kategori 1- 4 \\
\hline \multirow{5}{*}{2} & \multirow{5}{*}{$\begin{array}{l}\text { Informasi tambahan dalam } \\
\text { fasilitas websites }\end{array}$} & $\begin{array}{l}\text { 1. Informasi umum, Informasi khusus, Informasi } \\
\text { perniagaan, Informasi pendidikan }\end{array}$ \\
\hline & & $\begin{array}{l}\text { 2. Informasi umum, Informasi khusus, Informasi } \\
\text { pendidikan }\end{array}$ \\
\hline & & $\begin{array}{l}\text { 3. Informasi umum, Informasi khusus dan } \\
\text { Informasi perniagaan }\end{array}$ \\
\hline & & 4. Informasi umum dan Informasi khusus \\
\hline & & 5. bukan salah satu dari kategori 1 - 4 \\
\hline \multirow{4}{*}{3} & \multirow{4}{*}{ Penyediaan hubungan } & 1. G2C (Government to Citizen) \\
\hline & & 2. G2B (Government to Bussines) \\
\hline & & 3. G2G (Interagency Relationship) \\
\hline & & 4. Kombinasi \\
\hline \multirow{3}{*}{4} & \multirow{3}{*}{ Aksesbilitas } & 1. Kurang dari 5 detik \\
\hline & & 2. 5 detik - 10 detik \\
\hline & & 3. Lebih dari 10 detik \\
\hline \multirow{3}{*}{5} & \multirow{3}{*}{ Design } & 1. Animasi, Grafis, dan teks lengkap \\
\hline & & 2. Grafis dan teks \\
\hline & & 3. Animasi dan teks \\
\hline \multirow{3}{*}{6} & \multirow{3}{*}{ Jumlah Links Informasi } & 1. 1 tingkat \\
\hline & & 2. $2-3$ tingkat \\
\hline & & 3. lebih dari 3 tingkat \\
\hline
\end{tabular}


Penelitian ini mengambil lokasi di Pemerintahan Provinsi Jambi. Penulis melakukan observasi pada seluruh situs/website resmi Pemerintah Provinsi Jambi serta Kabupaten dan Kota untuk mendapatkan data-data yang bersifat primer. Data yang diperoleh melalui pemahaman secara tekstual dimasukkan dalam lembar coding sheet yang memuat kategori yang ditetapkan. Coding merupakan proses tarnsformasi data mentah ke dalam unit-unit yang memungkinkan membuat deskripsi karaketeristik isi yang relevan. Data yang ada dalam coding sheet dianalisa untuk menjawab pertanyaan dalam rumusan masalah.

\section{PEMBAHASAN}

Upaya pengembangan e-government yang merupakan bentuk pemanfaatan teknologi dari konsep open government menutup celah tindakan korupsi, kolusi dan nepotisme serta penyalahgunaan wewenang melalui transparansi dan akuntabilitas melalui pemanfaatan website ataupun aplikasi portal milik pemerintah daerah.(Mundy, 2013: 33) Pelaksanaan Open Government dengan memanfaatkan teknologi atau disebut dengan e-government telah di laksanakan oleh seluruh Kabupaten/Kota di Provinsi Jambi, namun terdapat beberapa daerah yang belum melaksanakannya secara optimal. Hal ini bisa dilihat dari beberapa website pemerintah daerah yang aktif tapi kemudian sulit untuk mengakses informasi. Provinsi Jambi terdiri dari 11 Kabupaten/Kota diantaranya: Kabupaten Sarolangun, Kabupaten Batanghari, Kabupaten Bungo, Kabupaten Kerinci, Kabupaten Muaro Tebo, Kabupaten Merangin, Kabupaten Muaro Jambi, Kabupaten Tanjung Jabung Timur, Kabupaten Tanjung Jabung Barat dan Kota Sungai Penuh serta Kota Jambi. Unutk mengetahui pelaksanaan e-government di pada Kabupaten/Kota serta Provinsi Jambi maka penulis menelusuri website masingmasing pemerintahan, sehingga didapatkan hasil sebagai berikut:

Tabel 2. Websites Pemerintah Daerah di Provinsi Jambi

\begin{tabular}{|c|c|c|c|}
\hline No & Remerintah Kabupaten/Kota & Situs Web & Status \\
\hline 1 & Kabupaten Kerinci & kerincikab.go.id & Alstif \\
\hline 2 & Kabupaten Merangin & meranginkab.go.id & Altif \\
\hline 3 & Kabupaten Sarolangun & sarolangunkab.go.id & Under restriction \\
\hline 4 & Kabupaten Batanghari & batangharikab.go.id & Altif \\
\hline 5 & Kabupaten Dluar J Jambi & muarojambikab.go.id & Aktif \\
\hline 6 & 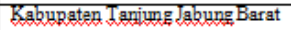 & tanjabbarkab.go.id & Aktif \\
\hline 7 & Kabupaten Taniung Rapung Timur & tanjabtimkab.go.id & Aktif \\
\hline 8 & Kabupaten Suaro Bunge & bungokgb.go.id & Aktif \\
\hline 9 & Kabupaten Tobo & tebokab.go.id & Under restriction \\
\hline 10 & Kota Jambi & jambikota.go.id & Alstif \\
\hline 11 & Kota Sungai Penuh & sungaipenuhkota.goid & Alktif \\
\hline
\end{tabular}

nanya $/ \zeta \%$ websıte pemerıntan yang aktıt dan sisanya tidak bisa diakses. Ketersediaan data dan informasi di setiap website juga belum lengkap dan terintegrasi secara menyeluruh. Salah satu contohnya adalah Pemerintah Provinsi Jambi dalam pengelolaan e-government yang justru masih tertinggal dibandingkan Kabupaten dan Kotanya padahal, Pemerintah Provinsi Jambi haruslah menjadi acuan bagi pemerintah Kabupaten dan Kotanya. Dari hasil analisa 
keseluruhan web pemda di Provinsi Jambi, penulis mendapatkan hasil sebagai berikut: a. Isi Informasi

Unsur terpenting dari sebuah tampilan yang efektif situs web di internet adalah isi (content) dan desain yang baik serta menarik. Sebuah situs web pemerintah daerah mempunyai persyaratan minimal untuk isi. Pengelola situs web pemerintah daerah harus mampu menentukan apa yang diharapkan oleh para pengguna mengenai apa yang seharusnya ada di situs web.(Susartono, 2016)

Pada aplikasinya mayoritas situs websites pemerintah Provinsi Jambi belum menyediakan isi informasi minimal pada tampilan homepage. Jika dicermati maka umumnya kekuranglengkapan isi minimal terletak pada tidak tercantumnya peraturan atau undang-undang produk dari masingmasing pemda serta tidak tersediannya buku tamu. Ketersediaan link informasi Peraturan Daerah (Perda) yang telah dikeluarkan oleh Pemerintah Daerah bersangkutan adalah vital karena melalui situs web pemerintah daerah inilah semua Perda yang telah dikeluarkan dapat disosialisasikan kepada masyarakat luas. Sedangkan links buku tamu sesungguhnya digunakan sebagai evaluasi dan monitoring terhadap umpan balik yang disampaikan masyarakat baik bagi Pemda maupun penyelenggaran e-government itu sendiri. Selain isi minimal seperti tersebut diatas, menurut Panduan Penyelengaraan Situs Web Pemda (Kominfo) isi informasi lainnya yang disajikan pada suatu situs web pemerintah daerah diserahkan sepenuhnya kepada masing-masing Penanggungjawab Situs dan Manajer Situs web pemerintah daerah, tergantung pada kondisi setempat dan kesediaan data serta informasi yang dimiliki oleh daerah bersangkutan. Isi informasi lainnya yang disediakan oleh kebanyakan situs web pemda umumnya berisi tentang informasi umum, khusus, pendidikan serta informasi perniagaan. Artinya, ini menunjukkan bahwa sebagian besar pemerintah daerah baik pemprov dan pemkot/pemkab memiliki motivasi guna membangun good governance dalam dunia virtual melalui penyediaan informasi yang lengkap kepada masyarakat. Namun begitu sebagian besar nampaknya masih ada beberapa situs websites Pemprov dan Pemda Jambi yang tidak memiliki kelengkapan informasi umum dan khusus, padahal ini merupakan sarana utama sebagai penyampaian pesan secara rutin bagi pihak masyarakat sebagai objek pemerintahan.

Keberadaan links informasi tambahan sesungguhnya merupakan media yang tepat untuk public relations bagi pemda yang bersangkutan, karena dengan informasi tersebut dimungkinkan masyarakat akan mengetahui banyak kemajuan dan eksistensi pemerintahan pemda yang bersangkutan yang akan memicu munculnya citra dan opini yang positif.(Widodo, 2015: 11) Ada beberapa situs web pemda justru menonjolkan informasi profile, kolom pimpinan daerah 
dalam bentuk opininya. Pada satu sisi ini merupakan representasi komunikasi pimpinan dengan warganya, tapi di sisi humas hal ini justru tidak etis. Selain isi minimal dan isi kelengkapan penempatan jumlah links informasi juga menjadi pertimbangan dalam tampilan situs web pemda. Jumlah links informasi merujuk pada kelengkapan informasi yang tidak menumpuk pada halaman muka (homepage) namun disebarkan melalui site-site yang dimiliki. Semakin banyak links maka akan menunjukan bahwa informasi yang tersedia semakin lengkap, dan tidak hanya itu tingkatan links juga merujuk pada kemudahan bagi pengunjung untuk memasuki websites lainnya yang berkaitan dengan informasi yang berada dalam situs website Pemprov Jambi. Yang menarik ternyata hampir sebagian situs web pemda menyediakan fasilitas search engine yaitu alat yang digunakan untuk mempermudah pengunjung situs untuk mencari informasi. Search engine yang disediakan bisa berbentuk pencarian arsip website namun juga pencarian informasi dalam arti luas.

\section{b. Evaluasi Penyediaan Links Hubungan} Ketersediaan links yang menghubungkan pihak pemda dengan institusi atau instansi lain yang berkait erat dengan kebutuhan dan kepentingan masyarakat merupakan jalan utama menuju tercapainya tahapan ke tiga atau ke empat dalam pengembangan egovernment. Links hubungan yang di maksud meliputi links Government to Government (G2G), Government to Business (G2B), Government to Consumers (G2C). (Sosiawan, 2014: 18) Bila dianalisis, maka hampir semua situs website Pemda menyediakan hubungan links antara Pemda dengan masyarakat sebagai objek pemerintahan, pihak institusi yang bergerak dalam bidang bisnis, serta pihak pemerintah daerah lainnya. Namun walaupun ada hubungan interagency tetapi mayoritas masih berbentuk links ke institusi yang masih dalam lingkup masing-masing pemda sendiri. Tidak ada situs website pemda yang diteliti membuat interagency ke pemda lainnya. Jikapun ada, maka umumnya hanya bersifat links biasa saja bukan menunjukkan adanya keterkaitan data ataupun interchange dan integrated data's. Jika hanya melihat pada jumlah links yaitu banyaknya loncatan informasi yang disediakan dalam satu site atau homepage (semakin banyak links yang disediakan maka akan semakin banyak informasi yang ditawarkan atau di tayangkan) maka umumnya paling banyak situs web pemda rata-rata memiliki jumlah links antara 50 hingga 50 keatas. Sementara jumlah minimalnya berkisar antara 30 links, sedangkan Jambi hanya memiliki jumlah links antara 15-20 links dan ini masih jauh dari kata cukup.

c. Evaluasi Aksesbilitas

Aksesbilitas merupakan kecepatan loading untuk tampil secara utuh dari semua beban suatu situs yang diukur dalam bilangan detik.(Lee, 2013: 9) 
Aksesbilitas yang dimiliki oleh situs web pemda umumnya menunujukkan kepemilikan aksesbilitas kurang dari 5 detik. Ini menunjukkan bahwa hampir semua pemda peduli akan pelayanan melalui media online sebab aksesbilitas lebih dari 5 - 10 detik akan menyebabkan pengguna situs enggan untuk menunggu sampai loading selesai. Bukan itu saja loading yang terlalu lama akan menyebabkan kurangnya nilai pelayanan dari pemda itu sendiri yang menyebakan tujuan penyelengaraan e-government menjadi percuma. Aksesbilitas yang lebih dari 10 detik dimungkinkan akan menghambat motivasi dari pengunjung situs, karena aksesbilitas rata-rata yang diminta oleh user pengunjung adalah berkisar antara 1 hingga 5 detik. Dari 11 Kabupaten/Kota yang ada di Provinsi Jambi, beberapa daerah yang aksesibilitasnya kurang dari 5-10 detik hanya Kabupaten Batanghari, Merangin dan Tanjung Jabung Timur, itu artinya 9 kab/kota masih berada di level rendah. Adapun situs web pemprov dan pemda lain aktif meskipun ada yang berstatus under restriction tak dipungkiri bahwa peningkatan implementasi e-government harus ditingkatkan bersama.

d. Evaluasi Umpan Balik

Ketersediaan umpan balik melalui e-mail kepada pihak Pemda dari masyarakat yang ditujukan kepada pejabat di lingkungan Pemda merupakan penyediaan sarana untuk menyampaikan suatu permintaan atau keterangan serta aspirasi. Pada implementasinya kebanyakan umpan balik melalui e-mail yang disediakan ditujukan kepada administratur website dan bukannya kepada pejabat yang terkait. Ini mengakibatkan bahwa proses umpan balik dari masyarakat apakah itu berkaitan dengan keluhan, saran atau permohonan tidak langsung dapat diterima atau di monitor oleh pejabat yang terkait. Kemudian, melalui pola e-mail yang langsung tertuju pada account pejabat yang bersangkutan tentunya akan memudahkan masyarakat berkomunikasi secara interpersonal kepada pejabat publik (walau dalam kontek virtual) sehingga keluhan, saran dan masukan dapat langsung diterima oleh sang pejabat publik.(Rakhmanov, 2014)

Meskipun pada prakteknya pesan tersebut akan disampaikan ke pejabat terkait, hal ini memperlambat respon yang bisa diterima masyarakat. Kabupaten Batanghari adalah salah satu pemerintah kabupaten yang telah menyediakan menu link e-lapor sebagai media aspirasi, keluhan atau saran dari masyarakat. $\mathrm{Hal}$ ini perlu diapresiasi dan dijadikan contoh bagi kabupaten lainnya dalam menerapkan egovernment yang maskimal.

\section{e. Evaluasi Visualisasi Dan Desain}

Visualisasi dan desain adalah merupakan aplikasi tampilan situs web yang terdairi atas animasi, grafis dan teks disertai penempatan layout dan navigasi menu. (Furuholt, 2014: 11) Secara umum tampilan situs web pemda yang ada menunjukkan yang tidak menggunakan 
animasi lebih dominan dibanding dengan yang menggunakan desain secara lengkap yang terdiri dari Animasi, Grafis dan teks. Pertimbangan hanya menggunakan grafis dan teks adalah karena faktor aksesbilitas. Dikhawatirkan apabila menggunakan animasi akan mengurangi kecepatan loading website. Situs web Pemprov Jambi dan $11 \mathrm{Kab} /$ Kota lainnya yang mengandalkan animasi dan teks nampaknya belum ada yang berani mencobanya dan kemungkinan alasan utama disini adalah kurangnya sumber daya teknis yang mengelola situs website pemda. Kalaupun ada yang menggunakan animasi, bentuk animasi yang digunakan adalah animasi sederhana dan umumnya digunakan untuk merujuk pada links-links penting atau untuk running text greeting. Penggunaaan logo dan simbol-simbol khas daerah banyak ditonjolkan oleh masingmasing situs pada setiap homepage. Bentuk homepage pada masing-masing websites Pemda memiliki identitas yang mudah dikenali, artinya pada masingmasing homepage dicantumkan nama dan simbol masing-masing Pemda. Gambar yang menarik sebagai simbol kedaerahan juga nampak dalam masing-masing websites. Dari segi sistem navigasi, dapat dicermati bahwa pola menu informasi yang tersedia adalah memiliki kesamaan yaitu menggunakan sistem menu utama, menu tambahan, informasi / berita umum dan informasi khusus serta fasilitas links keberbagai alamat situs lainnya. Pola yang seragam ini sepertinya menjadi tipikal dari semua situs Pemda, namun pada sisi lain menyebabkan kurang beragamnya situs yang tersedia. Pada segi penyusunan lay out sebagai strategi kreatif dalam penyampaian informasi. Jika dilihat dari tipe lay out nya maka semuanya menggunakan tipe mondrian yaitu pembagian dua atau lebih bentuk persegi panjang dengan penggunaan bentuk garis dan batang secara tegas, sementara format yang digunakan adalah menggunakan format the outline; yaitu format yang digunakan untuk mengkomunikasikan komponen kunci pesan dengan menggunakan bahasa pernyataan yang luas dan bentuknya mirip gaya dalam penulisan berita atau artikel.

\section{f. Evaluasi Manajemen pengelolaan situs}

Orientasi pengelolaan situs pemerintah daerah tidaklah seperti web tradisional yang hanya memerlukan satu orang webmaster, namun terdiri struktur organisasi yang sistematis. Menurut panduan dari Kominfo maka pengelolaan dan penanggung jawab situs dilakukan oleh:

a) Pelindung (Gubernur/Bupati/Walikota)

b) Penanggungjawab Situs Web Pemerintah Daerah (eselon tertinggi pada organisasi struktural Pemerintahan Daerah)

c) Manajer Situs (eselon satu tingkat dibawah eselon tertinggi pada organisasi struktural Pemerintahan Daerah) 
d) Tim Pengelola (sejumlah pegawai Pemerintah Daerah yang mampu, serta mempunyai standar kompetensi di bidang teknologi informasi)

e) Tim Asistensi (para eselon satu tingkat dibawah eselon tertinggi pada organisasi struktural pemerintah daerah, mewakili unit-unit kedinasan yang ada di daerah) (Kominfo, 2002)

Secara umum terlihat bahwa pengelolaan situs web pemda masih belum sesuai dengan panduan penyelenggaraan situs web pemda yang dikeluarkan Kominfo. Artinya bahwa banyak pemda masih "setengah hati" dalam keterlibatan pengelolaan situs. Ini bisa dimengerti karena dalam konteks tertentu pihak pejabat publik bukan lahir dari generasi internet sehingga ada semacam "gagap teknologi" yang mempengaruhi keterlibatannya secara langsung dalam pengelolaan situs. Pengelolaan situs diserahkan pada badan yang memiliki keterkaitan dengan penyampaian informasi disini bila tidak Kantor Humas dan Informasi maka diserahkan pada Kantor Pengolahan Data Elektronik. Penyerahan pada dua badan tersebut sesungguhnya tidak salah sebatas dalam konteks manajerial dan pengelolaan, namun bila tidak ada sinergi dan kerjasama dengan instansi di lingkungan pemda maka umumnya informasi yang disampaikan dalam web tidak akan lengkap. Selain itu, ke-tidakadaan hal tersebut menyebabkan integritas layanan transakisonal yang diharapkan pada setiap situs pemda tidak akan terwujud.

\section{KENDALA UTAMA YANG DIHADAPI}

Bebeberapa kondisi awal di lapangan menunjukkan beberapa indikasi permasalahan dalam upaya memutuskan penerapan e-government di Provinsi Jambi. Kondisi tersebut berupa:

a) Belum terintegrasinya sistem yang dibangun. Beberapa kabupaten/kota ataupun instansi di pemerintahan daerah telah memiliki aplikasi atau sistem informasi, namun biasanya setiap sistem yang dikembangkan terpisah satu sama lain. Hal ini terjadi karena kebutuhan setiap instansi yang mengembangkannya berbeda antara yang satu dengan yang lain, atau dengan kata lain antara satu sistem dengan sistem lainnya tidak terintegrasi. Dengan tidak terintegrasinya sistem yang ada, maka kesulitan yang akan dihadapi adalah ketika kita membutuhkan suatu data atau informasi yang berasal dari berbagai sumber data, karena karakteristik data atau informasi yang berasal dari beberapa sistem informasi yang ada memiliki perbedaan format atau standart dari aturan yang ada. Data dan informasi yang terpisah secara fungsional maupun secara fisik seringkali menyebabkan tujuan dari adanya komputerisasi untuk memperoleh data secara tepat, cepat dan terkini menjadi tidak tercapai. 
b) Sarana dan prasarana komputer beserta jaringan yang kurang mendukung. Lingkungan perkantoran merupakan pusat informasi pemerintahan. Dengan terbatasnya sarana dan prasarana komputer serta jaringan akan memberikan tingkat pengelolaan informasi di kantor pusat. Kondisi seperti ini akan mengakibatkan lalu lintas data menjadi tidak optimal, kebutuhan informasi dan data menjadi sangat sulit untuk dapat langsung diperoleh, sehingga proses akses atas informasi di kantor pusat data serta pertukaran informasi antar satu kantor atau unit dengan kantor atau unit yang lain menjadi sangat lambat. Hal inilah yang menyebabkan efisiensi dan efektifitas kinerja pada setiap instansi menjadi berkurang.

c) Terbatasnya Sumber Daya Manusia. Kebutuhan sumber daya manusia yang berkualitas dan paham serta mengerti dan ahli di bidang teknologi informasi mash sangat sulit didapatkan. Sumber daya manusia dibeberapa kantor Pemerintahan Daerah masih sangat terbatas, terlebih dengan ditunjukkannya kesadaran para pimpinan di kantor pemerintahan daerah mengenai pentingnya membangun suatu unit pelayanan teknis yang khusus menangani bidang teknologi informasi masih sangat kurang. d) Kurangnya regulasi dan peraturan daerah yang mendukung perkembangan e-government. Kebijakan dan regulasi yang dikeluarkan oleh pemerintah daerah pada saat ini masih terlihat kurang. Karena prinsip keterbukaan bagi setiap penyelenggara daerah menjadi hambatan formal agar masyarakat dapat mengakses setiap kebijakan yang ada. Untuk itulah diperlukan keterbukaan secara luas di segala bidang pemerintahan, agar konsep clean governance dalam menghasilkan good governance menuju open government dapat tercapai.

\section{KESIMPULAN DAN SARAN}

\section{Kesimpulan}

Simpulan dan penawaran solusi jika dikaitkan dengan bentuk ideal yang diharapkan sebagai sarana e-government maka dapat dikatakan websites Pemda di Provinsi Jambi yang ada masih berfungsi sebagai media informatif atau kehumasan saja dan bukannya media interaktif apa lagi jika dikaitkan dengan panduan yang dikeluarkan Kominfo, maka status dari websites Pemda di Provinsi Jambi masih pada tahapan pematangan yaitu masih dalam kategori penyediaan informasi interaktif dan pemuatan antar hubungan dengan lembaga lain. Padahal kesempurnaan untuk menjadi $e$ government yang sesungguhnya 
memerlukan 4 tahapan. Dari sini dapat disimpulkan bahwa pengelolaan situs-situs Pemda yang ada di Indonesia masih berupa company profile atau sebatas iweb presence saja. Layanan aplikasi yang dibutuhkan sebagai sarana e-government seperti layanan pembuatan KTP, eemployment, layanan hukum dan sebagainya nampaknya masih jauh bahkan rintisannyapun masih belum kelihatan dan ini merupakan tantangan tersendiri bagi semua Pemda di Provinsi Jambi tersebut untuk meningkatkan status e-government mereka sampai pada tahapan pemantapan yaitu penyediaan transaksi pelayanan publik serta aplikasi pelayanan government to government (G2G), government to business (G2B) dan government to consumers (G2C). Agar sampai ke sana, faktor perubahan kultur penyelenggara Pemda di Provinsi Jambi serta faktor-faktor pendukung implementasi e-government perlu mendapat perhatian serius. Dengan pengembangan layanan e-government, maka penyelenggaraan pemerintahan beralih menjadi berbasis elektronik. Ini yang perlu disadari oleh birokrat agar memiliki kemampuan untuk secara cepat dan tepat mengaitkan diri dengan perkembangan di bidang teknologi informasi dan tuntutan keterbukaan dari masyarakat. Hakekat tujuan diterapkannya e-Goverment adalah agar pemerintah dapat menerapkan suatu praktik yang disebut sebagai good governance berupa suatu kontrak sosial yang menuntut demokratisasi terhadap pelaksanaan administrasi pemerintahan. Teknologi informasi seperti e-Goverment merupakan tool serta enabler untuk penerapan good government melalui penyelenggaraan administrasi pemerintahan yang akuntabel, transparan dan ada partisipasi publik yang signifikan. Untuk itu maka diperlukan suatu model manajemen dan pengelolaan isi situs web pemerintah daerah guna mendukung tercapainya e-government yang optimal.

\section{Saran}

1. Hendaknya Pemerintah Provinsi Jambi segera mengeluarkan aturan-aturan mengenai penerapan e-government agar dalam pelaksanaannya tidak mengalami hambatan dan dalam koridorkoridor yang diatur dalam peraturan perundang-undangan yang berlaku.

2. Website yang ada saat ini hendaknya lebih dioptimalkan kembali terutama yang ada pada SKPD khususnya yang berkaitan dengan informasi-informasi yang sangat dibutuhkan bagi masyarakat.

3. Hendaknya Pemerintah Provinsi Jambi mempertimbangkan kembali pengalokasian pembiayaan pengembangan infrastruktur dan jaringan e-government yang dianggarkan secara bertahap karena hal tersebut akan menimbulkan kendala-kendala baru di tahun yang akan datang. 
4. Untuk penelitian selanjutnya, diharapkan dapat melakukan penelitian yang lebih mendalam mengenai kebijakan penerapan $e$ government karena hal ini menyangkut kewajiban pemerintah daerah untuk memberikan informasi yang seluas-luasnya kepada masyarakat.

\section{DAFTAR PUSTAKA}

[DEPKOMINFO] Departemen Komunikasi dan Informasi (2003), "Kebijakan dan Pengembangan Startegi Nasional Pengembangan E-Government (Inpres No. 3 tahun 2003): Panduan Penyusunan Rencana Induk Pengembangan E-Government Lembaga versi 1.0".

Pemerintah Republik Indonesia, Presiden Republik Indonesia.2003. " Intruksi President Nomor 3 Tahun 2003 Tentang Kebijakan dan Strategi Nasional Pengembangan Egovernment. Indonesia".

Andrianto, Nico. 2015. Good EGovernment : Transparansi dan Akuntabilitas Publik Melalui EGovernment. Malang : Banyu Media Publishing.

Anggono, Bambang Dwi, (2013), "Urunan Project e-Government Kolaborasi Pengembangan e-Government Nasional dalam Perspektif Otonomi Daerah", Prosiding Konferensi Nasional Teknologi Informasi \& Komunikasi untuk Indonesia, 3-4 Mei 2013, Institut Teknologi Bandung.

Djumadal, J. Surat, (2013), "Penerapan eGovernment dan Berbagai Kendala di Pemerintah Provinsi Daerah Istimewa Yogyakarta", Prosiding Konferensi Nasional Teknologi Informasi \& Komunikasi untuk Indonesia, 3-4 Mei 2013, Institut Teknologi Bandung.

Dwiyanto, Agus. 2017. Mewujudkan Good Governance Melalui Pelayanan Publik. Yogyakarta: Gadjah Mada University Press.
Furuholt, Bjorn; dan Wahid, Fathul. (2014). "E-government Challenges and the Role of Political Leadership in Indonesia: the Case of Sragen". Proceedings of the 41st Hawaii International Conference on System Science, 2014. IEEE. 1530-1605/14.

Gulati ,Girish J.; “Jeff”; Yates, David J.; dan Williams, Christine B. (2015). "Understanding the Impact of Political Structure, Governance and Public Policy on E-government". Massachusetts : Bentley University. 45th Hawaii International Conference on System Sciences. DOI 10.1109/HICSS.2015.617. IEEE. 978-0-7695-4525-7/15.

Hutter, Michael. 2016. "Efficiency, Viabillity, and the New Rules of the Internet" dalam European Journal of Law an Economics. Netherlands : Kluwer Academic Publisher.

Indrajit, Richardus E dkk. 2014. EGovernment Strategi Pembangunan dan Pengembangan Sistem Pelayanan Publik Berbasis Teknologi Digital. Yogyakarta: Andi.

J. Moleong, Lexy. 2005. Metodologi Penelitian Kualitatif, Edisi Revisi. Bandung : PT. Remaja Rosdakarya.

Junaidi. 2015. E-Government dalam Bingkai Reformasi Administrasi Publik Menuju Good Governance. JKAP Program Pasca Sarjana Magister Administrasi Publik Universitas Gadjah Mada volume 9. No. 1, 59-60.

Lee, Nag Yeon. (2013). Modul 3: Penerapan e-Government. Academy Modules (Bahasa Version).United nation : Asian and Pacific Training Centre for Information and Communication Technology for Development (APCICT). Diakses pada $12 \quad$ Mei 2018. http://www.unapcict.org/academy/aca demy/academy-modules/bahasaindonesia-version.

Mundy, D., \& Musa, B. 2013. Towards a Framework for eGovernment Development in Nigeria. Electronic Journal of e-Government. 
Rakhmanov. (2014). "The barriers affecting

E-government development in Uzbekistan". South Korea: Seoul National University. Fourth International Conference on Computer Sciences and Convergence Information Technology. 978-0-7695-3896-9/09.

Sosiawan, Edwi Arief. 2014. Model Management Komunikasi dan Administrasi Back Office EGovernment sebagai Media Pelayanan Publik. Jurnal IImu Komunikasi. Volume 7. Nomor 1. Yogyakarta: Jurusan IImu Komunikasi UPN “Veteran”.

Susartono. 2016. E-Government di Indonesia. Jurnal Administrasi Negara Fakultas IImu Sosial dan IImu Politik Universitas Sebelas Maret Surakarta volume 2 No. 1, 2-5.
Widodo, Joko. 2015. Good Governance, Telaah dari Dimensi Akuntabilitas dan Kontrol Birokrasi Pada Era Desentralisasi dan Otonomi Daerah. Insan Cendekia: Surabaya. 